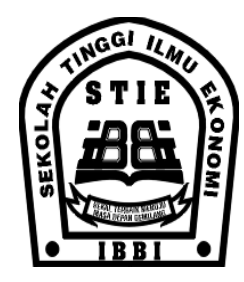

ISSN 1858-3199

JURNAL

MANAJEMEN BISNIS

STIE IBBI

\title{
PENGARUH LOKASI, KUALITAS PRODUK DAN KUALITAS PELAYANAN \\ TERHADAP KEPUASAN KONSUMEN PASAR TRADISIONAL (STUDI KASUS PASAR TRADISIONAL DI KECAMATAN MEDAN JOHOR)
}

\author{
Maretta Ginting \\ etaitinkcantix@yahoo.com \\ Ahmad Saputra \\ Saputra_damha@yahoo.com \\ Program Studi S-1 Manajemen STIE IBBI
}

\begin{abstract}
ABSTRAC
Customer satisfaction is feeling comparing consumers after what is expected with the results obtained consumers. Keeping satisfaction is very important in all fronts business because only with maintain and increase customer satisfaction business can survive and develop.Similarly with the phenomenon of customer satisfaction in the traditional market traditional and parties parties related with the condition of traditional traders must shoulder each other to increase satisfaction of consumers who shop in traditional market so that consumers keep afloat buy and meet the needs of their product from traditional traders

Traditional markets in medan johor sub-district should get organized to increase customer satisfaction buy in that market. Discontent shopping problems can be seen from the level of the complaints of the community to the trader. And may also evident from a fall in the number of consumers who shop, halting his intention because look at the products sold or for not comfortable with the short market location that requires it difficult for them to a private car to the market. Hence researchers interested to know how the influence of the location and the quality of products and the quality of the service for customer satisfaction traditional markets in medan johor sub-district. This research survey by picking 100 consumers traditional markets in medan johor sub-district to know the influence of the location and the quality of the product and the quality of the service for customer satisfaction tardisional market in medan johor sub-district.

The testing can conclude that the variables in the research is independent site, the quality of the product, and service quality can show the variations customer satisfaction. While simultaneously test results showed that location the quality of the product, and service quality appropriate to examine the dependent variable; the customer satisfaction
\end{abstract}

Keyword: Location, Quality, Service and Satisfaction

\section{ABSTRAK}

Kepuasan konsumen adalah perasaan konsumen setelah membandingkan apa yang diharapkan dengan hasil yang didapat konsumen. Menjaga kepuasan sangat penting dalam semua lini bisnis karena hanya dengan mempertahankan dan meningkatkan kepuasan konsemen bisnis bisa bertahan dan berkembang. Demikian juga dengan fenomena kepuasan konsumen di pasar tradisional, pedagang pasar tradisional dan pihak pihak yang terkait dengan kondisi pedagang tradisional harus bahu membahu meningkatkan kepuasan konsumen yang berbelanja di pasar tradisional agar konsumen tetap bertahan membeli dan memenuhi kebutuhan produk mereka dari pedagang tradisional.

Pasar Tradisional di Kecamatan Medan Johor harus berbenah untuk meningkat kepuasan konsumen 

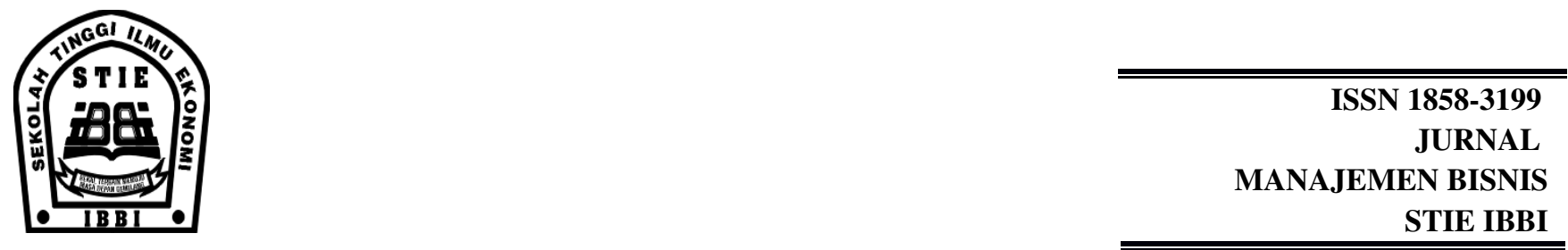

yang berbelanja di pasar tersebut. Masalah ketidakpuasan berbelanja dapat terlihat dari tingkat keluhan masyarakat kepada pedagang. Dapat juga terlihat dari penurunan jumlah konsumen yang berbelanja, mengurungkan niatnya karena melihat kondisi produk yang dijual atau karena tidak nyaman dengan sempitnya lokasi pasar yang mengharuskan mereka sulit membawa kendaraan pribadi ke pasar tersebut. Oleh karena itu peneliti tertarik untuk mengetahui bagaimana pengaruh lokasi, kualitas produk dan kualitas pelayanan terhadap kepuasan konsumen pasar tradisional di Kecamatan Medan Johor. Penelitian ini melakukan survey dengan memilih 100 konsumen Pasar Tradisional di Kecamatan Medan Johor untuk mengetahui pengaruh lokasi, kualitas produk serta kualitas pelayanan terhadap kepuasan konsumen pasar tardisional di Kecamatan Medan Johor.

Hasil pengujian dapat disimpulkan bahwa variabel-variabel independen dalam penelitian ini yakni lokasi, kualitas produk, dan kualitas pelayanan mampu menerangkan variasi kepuasan konsumen. Sedangkan hasil uji secara simultan memperlihatkan bahwa lokasi, kualitas produk, dan kualitas pelayanan layak untuk menguji variabel dependen, yakni kepuasan konsumen

Keyword : Lokasi, Kualitas Produk, Kualitas Pelayanan serta Kepuasan Konsumen

\section{PENDAHULUAN}

Sampai saat ini pasar tradisional masih memegang peranan yang penting di masyarakat. Pasar tradisional memiliki keunikan tersendiri karena penjual dan pembeli bertemu secara langsung, melakukan tawar menawar secara langsung, harga tidak tetap tergantung keahlian konsumen melakukan penawaran, hal tersebut memberikan keasikan tersendiri pada konsumen dalam melakukan transaksi. Meskipun saat ini pasar modern seperti mal - mal berkembang dengan pesat di setiap kota di Indonesia, tetapi keberadaan pasar tradisional ini tetap memegang peranan penting dalam memenuhi kebutuhan pokok masyarakat. Masyarakat Medan biasanya menyebut Pasar tradisional dengan sebutan Pajak. Di kota Medan terdapat 52 pasar tradisonal atau pajak resmi yang dinaungi oleh PD Pasar. Pasar Tradisional di Kecamatan Medan Johor adalah beberapa pasar tradisional yang resmi di bawan naungan PD Pasar Medan. Di Pasar Tradisional di Kecamatan Medan Johor juga terdapat kantor cabang PD. Pasar Medan.

Lokasi pasar tradisional di Medan biasanya terletak diantara rumah warga, dan tak jauh dari jalan raya. Lokasi Pasar Tradisional di Kecamatan Medan Johor tidak luas seperti Plaza Modern di Medan. Sebenarnya lokasi Pasar tradisional yang sempit itu merupakan suatu masalah yang cukup pelik mengingat banyaknya masyarakat yang berbelanja di pasar tradisional ini dibanding dengan pasar modern yang lokasinya lebih luas luas tetapi jumlah pengunjungnya hanya banyak di hari hari tertentu saja.

Produk yang di jual di Pasar Tradisional di Kecamatan Medan Johor adalah produk - produk kebutuhan pokok yang biasanya di konsumsi masyarakat, seperti sembilan bahan pokok (sembako), sayur sayuran, buah - buahan, ikan, pakaian-pakaian sederhana dll. Kebutuhan yang dijual di pasar tradisional ini adalah produk - produk dengan kualitas sederhana jadi konsumen tidak akan menemukan beras organik atau sayuran organik yang mahal di pasar ini.

Menjaga kepuasan sangat penting dalam semua lini bisnis karena hanya dengan mempertahankan dan meningkatkan kepuasan konsemen bisnis bisa bertahan dan berkembang. Demikian juga dengan fenomena kepuasan konsumen di pasar tradisional, pedagang pasar tradisional dan pihak pihak yang terkait dengan kondisi pedagang tradisional harus bahu membahu meningkatkan kepuasan konsumen yang berbelanja di pasar tradisional agar konsumen tetap bertahan membeli dan memenuhi kebutuhan produk mereka dari pedagang tradisional. Beberapa konsumen yang datang dan berniat berbelanja terkadang mengurungkan niatnya karena melihat kondisi produk yang di jual atau terkadang bisa juga karena tidak nyaman dengan sempitnya lokasi pasar yang mengharuskan mereka sulit membawa kendaraan pribadi ke pasar tersebut. Berdasarkan uraian masalah 

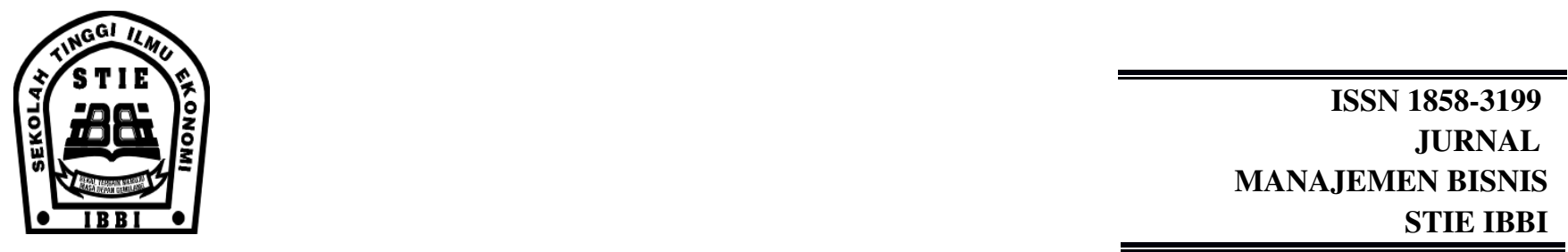

di atas maka penulis tertarik memilih judul "Pengaruh Lokasi, Kualitas Produk dan Kualitas Pelayanan terhadap Kepuasan Konsumen Pasar Tradisional (Studi Kasus Pasar Tradisional di Kecamatan Medan Johor)”

Berdasarkan latar belakang masalah diatas, maka dapat dirumuskan permasalahan dalam penelitian ini adalah sebagai berikut : "Bagaimana Pengaruh Lokasi, Kualitas Produk dan Kualitas Pelayanan terhadap Kepuasan Konsumen Pasar Tradisonal (Studi Kasus Pasar Tradisional di Kecamatan Medan Johor) ?”.

Tujuan penelitian ini adalah : "untuk mengetahui Bagaimana Pengaruh Lokasi, Kualitas Produk dan Kualitas Pelayanan terhadap Kepuasan Konsumen Pasar Tradisonal (Studi Kasus pasar Tradisional di Kecamatan Medan Johor).

\section{TINJAUAN LITERATUR}

Pasar tradisional sebagai sebuah tempat bertemunya para pembeli dan penjual, melakukan transaksi secara langsung dengan sistem yang sederhana.. Dalam rangka mencapai kepuasan konsumen tersebut pasar tradisional harus memperhatikan faktor - faktor yang mempengaruhi kepuasan konsumen. Berdasarkan berbagai literarur dipilih beberapa faktor yang dianggap paling signifikan memepengaruhi kepuasan konsumen di pasar tradisional, beberapa faktor yang berpengaruh tersebut diantaranya adalah lokasi, kualitas produk dan kualitas pelayanan.

Lokasi adalah tempat atau daerah dimana pedagang menjual dagangannya. Lokasi yang strategis sangat mempengaruhi keberlangsungan sebuah usaha. Lokasi yang strategis membuat konsumen tertarik untuk datang dan memilih melakukan transaksi pembelian di tempat tersebut. Pengusaha harus mempertimbangkan untuk selalu melalukan perbaikan lokasi karena lokasi yang baik sangat mempengaruhi kepuasan konsumen dan pada akhirnya konsumen akan tetap berkunjung ke tempat tersebut.

Kualitas produk adalah keunggulan sebuah produk yang akan dirasakan oleh konsumen. Kualitas produk biasanya memiliki standardnya masing - masing. Para pedagang harus memperhatikan kualitas produk yang mereka jual agar tercipta kepercayaan dari para konsumen akan kualitas produk yang mereka beli. Jika penjual kurang memperhatikan masalah kualitas produk maka akan terjadi penurunan tingkat pembelian tetapi jika penjual sangat memperhatikan kualitas produk makan akan terjadi kenaikan jumlah pembelian disebabkan tingkat kepuasan konsumen yang meningkat akibat baiknya tingkat kualitas produk.

Kualitas pelayanan adalah kualitas aktifitas yang ditawarkan produsen atau penjual yang terjadi akibat adanya interaksi antara produsen atau penjual dengan konsumen. Kualitas pelayanan sangat memepengaruhi tumbuh kembang suatu usaha, oleh karena itu pengusaha dituntut untuk selalu melakukan pembenahan terhadap kualitas pelayanan yang mereka tawarkan. Konsumen setiap saat akan menuntut perbaikan kualitas pelayanan dari para penguasaha, jika kosumen puas akan kualitas pelayanan maka konsumen akan melakukan pembelian ulang. Oleh karena itu kualitas pelayanan sangat mempengaruhi kepuasan konsumen.

Kepuasaan konsemen adalah perasaan konsumen saat membandingkan harapan dengan apa yang diterima setelah membeli atau mengkonsumsi produk barang atau jasa. Terdapat beberapa faktor yang memepengaruhi konsumen diantaranya Lokasi, kualitas produk, kualitas pelayanan dan beberapa faktor lain lain. Berdasarkan penjelasan diatas, kerangka konseptual dalam penelitian ini dapat digambarkan sebagai berikut : 


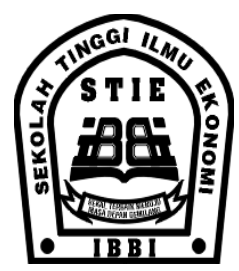

ISSN 1858-3199

JURNAL

MANAJEMEN BISNIS

STIE IBBI

\section{KERANGKA BERFIKIR}

\section{Gambar 1 \\ Bagan Kerangka Konseptual}

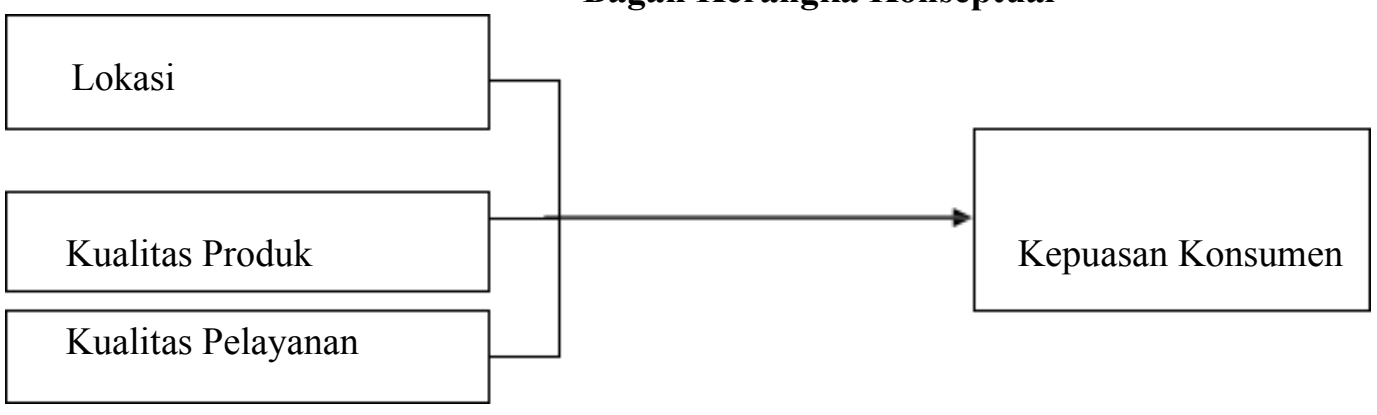

Berdasarkan kerangka konseptual yang telah dikemukakan di atas, maka hipotesis dari penelitian ini adalah : Lokasi, kulalitas produk dan kualitas pelayanan berpengaruh terhadap kepuasan konsumen Pasar Tradisional (Studi Kasus Pasar Tradisional di Kecamatan Medan Johor )”

\section{METOLOGI PENELITIAN}

Metode penelitian yang digunakan oleh penulis adalah metode penelitian deskriptif kuantitatif. Penelitian ini dilakukan untuk mengetahui dan membuktikan pengaruh variabel lokasi, kualitas produk dan kualitas pelayanan terhadap kepuasan konsumen pasar tradisional (studi kasus Pasar Tradisional di Kecamatan Medan Johor)

Lokasi penelitian adalah tempat dimana peneliti melakukan penelitian untuk memperoleh data - data yang diperlukan. Adapun lokasi penelitian ini dilakukan di Pasar Tradisional di Kecamatan Medan Johor. Waktu penelitian direncanakan mulai bulan Desember 2013 sampai bulan Agustus 2014.

Responden yang menjadi sampel berjumlah 100 orang. Penentuan ini dilakukan berdasarkan syarat minimal sampel data terdistribusi normal statistik adalah 30 sampel. Dilakukan penambahan 70 orang dengan anggapan bahwa semakin banyak jumlah responden maka akan semakin baik dengan memperkirakan waktu pengambilan sampel yang cukup lama.

Teknik sampling dalam penelitian ini adalah probability sampling karena memberikan peluang yang sama bagi setiap anggota populasi untuk dipilih menjadi sampel.

Teknik pengumpulan data yang digunakan dalam penelitian ini adalah sebagai berikut:

1. Wawancara (Interview) yaitu melakukan tanya jawab secara langsung dengan pedagang dan konsumen Pasar Tradisional di Kecamatan Medan Johor mengenai masalah yang diteliti.

2. Daftar Pertanyaan ( questionaire) yaitu yaitu berupa angket yang harus diisi oleh responden tentang masalah yang diteliti. Responden disini adalah konsumen Pasar Tradisional di Kecamatan Medan Johor.

3. Pengamatan (observation) yaitu melakukan pengamatan langsung mengenai kegiatan yang dilakukan di Pasar Tradisional di Kecamatan Medan Johor. 

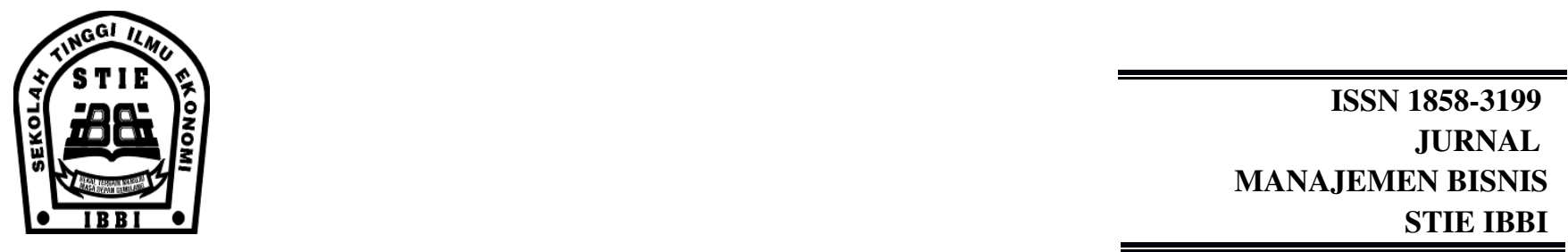

Alat uji yang dipergunakan untuk menganalisis hipotesis dalam penelitian ini adalah Analisis Regresi Linier Berganda (Multiple Regression Analysis) untuk menguji variabel bebas lokasi, kualitas Produk serta Kualitas pelayanan terhadap variabel terikat kepuasan konsumen, dengan model persamaan sebagai berikut :

$$
\mathbf{Y}=\mathbf{a}+\mathbf{b} 1 \mathbf{X} 1+\mathbf{b} 2 \mathbf{X} 2+\mathbf{b} 3 \mathbf{X} 3
$$

Dimana:

$$
\begin{aligned}
\mathrm{Y} & =\text { Kepuasan Konsumen } \\
\mathrm{a} & =\text { konstanta } \\
\mathrm{b} 1 & =\text { Koefisien variabel X1 } \\
\mathrm{b} 2 & =\text { Koefisien variabel X2 } \\
\mathrm{b} 3 & =\text { Keofisien variabel X3 } \\
\mathrm{X} 1 & =\text { Lokasi } \\
\mathrm{X} 2 & =\text { Kualitas Produk } \\
\mathrm{X} 3 & =\text { Kualitas Pelayanan } \\
\mathrm{e} & =\text { Tingkat kesalahan (error of term) }
\end{aligned}
$$

Data - data yang sudah dikumpulkan kemudian dilakukan uji hipotesis sebagai berikut:

1. Uji determinasi (R2).

Identifikasi koefisien determinan ditujukan untuk mengetahui seberapa besar kemampuan model dalam menerangkan variable terikat.

2. Uji t ( Uji secara Parsial)

Uji t bertujuan untuk melihat pengaruh variable bebas yaitu lokasi, kualitas produk dan kualitas pelayanan terhadap kepuasan konsumen pasar tradisional (Studi Kasus Pasar Tradisional di Kecamatan Medan Johor )". secara parsial.

\begin{tabular}{|c|c|c|c|c|c|}
\hline \multirow[t]{2}{*}{ Model } & \multicolumn{2}{|c|}{$\begin{array}{c}\text { Unstandardized } \\
\text { Coefficients }\end{array}$} & \multirow{2}{*}{\begin{tabular}{|c|}
$\begin{array}{c}\text { Standardized } \\
\text { Coefficients }\end{array}$ \\
Beta \\
\end{tabular}} & \multirow[t]{2}{*}{$\mathbf{t}$} & \multirow[t]{2}{*}{ Sig. } \\
\hline & B & Std. Error & & & \\
\hline (Constant) & 1.603 & 1.354 & & 1.184 & .239 \\
\hline Lokasi & .231 & .084 & .204 & 2.751 & .007 \\
\hline Kualitas_Produk & .375 & .122 & .391 & 3.068 & .003 \\
\hline Kualitas Pelayanan & .300 & .126 & .291 & 2.386 & .019 \\
\hline
\end{tabular}

3. Uji F

Uji F bertujuan untuk melihat pengaruh variable bebas yaitu lokasi, kualitas produk dan kualitas pelayanan terhadap kepuasan konsumen pasar tradisional (Studi Kasus Pasar Tradisional di Kecamatan Medan Johor)". secara serentak

\section{Hasil Penelitian}

Dari hasil uji regresi berganda diperoleh koefisien regresi, nilai $t_{\text {hitung }}$ dan tingkat signifikansi sebagaimana ditampilkan pada Tabel 5.7 berikut ini:

Tabel 2

Hasil Uji Regresi Berganda 

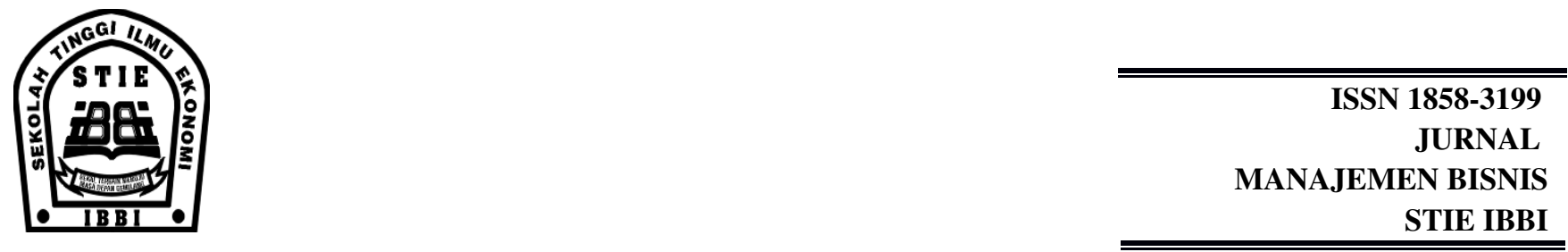

Dari persamaan regresi di atas dapat diartikan bahwa:

1. Variabel Lokasi $\left(\mathrm{X}_{1}\right)$ mempunyai pengaruh yang positif terhadap kepuasan konsumen (Y) sebesar 0,231. Variabel kualitas produk $(0,231)$ mempunyai pengaruh yang paling kecil terhadap kepuasan konsumen bila dibandingkan dengan variabel bebas yang lain.

2. Variabel kualitas produk $\left(\mathrm{X}_{2}\right)$ mempunyai pengaruh yang positif terhadap kepuasan konsumen $(\mathrm{Y})$ sebesar 0,375. Variabel kualitas pelayanan $(0,375)$ memiliki pengaruh paling besar terhadap kepuasan konsumen bila dibandingkan dengan dengan variabel bebas lain.

3. Variabel kualitas pelayanan $\left(\mathrm{X}_{3}\right)$ mempunyai pengaruh yang positif terhadap kepuasan konsumen $(\mathrm{Y})$ sebesar 0,300. Variabel kualitas pelayanan $(0,300)$ memiliki pengaruh yang besar, tetapi lebih kecil pengaruhnya bila dibandingkan dengan variable kualitas produk $(0,375)$.

Uji Goodness of Fit

1. Koefisien Determinasi $\left(\mathbf{R}^{2}\right)$

Tabel 3

Koefisien Determinasi Model Summary

\begin{tabular}{|c|r|r|r|c|}
\hline Model & R & R Square & $\begin{array}{c}\text { Adjusted R } \\
\text { Square }\end{array}$ & $\begin{array}{c}\text { Std. Error } \\
\text { of the } \\
\text { Estimate }\end{array}$ \\
\hline 1 & $.776^{\mathrm{a}}$ & .603 & .590 & 2.460 \\
\hline
\end{tabular}

a. Predictors: (Constant), Lokasi, Kualitas_Produk, Kualitas_Pelayanan

b. Dependent Variable: Kepuasan_Konsumen

Sumber: Data primer yang diolah, 2014

Dari Tabel 3 terlihat bahwa angka $\mathrm{R}$ yang dihasilkan sebesar 0,776. Hal ini menunjukkan bahwa korelasi atau hubungan antara kepuasan konsumen (variabel dependen) dengan nilai variabel-variabel independennya (variabel lokasi, kualitas produk, dan kualitas pelayanan) adalah kuat. Dikatakan kuat karena 0,776 >0,05.

Angka koefisien determinasi atau $\mathrm{R}^{2}$ yang dihasilkan adalah sebesar 0,603 . Namun, untuk jumlah variabel independen lebih dari 2 (dalam kasus ini ada 3 variabel) lebih baik digunakan Adjusted $R$ Square yaitu sebesar 0,590. Hal ini berarti 59\% variasi dari kepuasan konsumen bisa dijelaskan oleh ketiga variabel independen yang digunakan dalam persamaan regresi. Sedangkan selebihnya yaitu 41\% (100\% - 59\%) dijelaskan atau diprediksi oleh variabel lain di luar ketiga variabel yang digunakan dalam penelitian ini.

Semakin kecil Standar Error of Estimate (SEE) maka akan membuat persamaan regresi semakin tepat dalam memprediksi variabel dependen. Dalam penelitian ini angka SEE adalah sebesar 2,460.

\section{Uji Signifikasi Simultan (Uji F)}

Uji F dimaksudkan untuk mengetahui pengaruh secara bersama-sama (simultan) variabel bebas (lokasi, kualitas produk, dan kualitas pelayanan) terhadap variabel terikat (kepuasan konsumen ). 


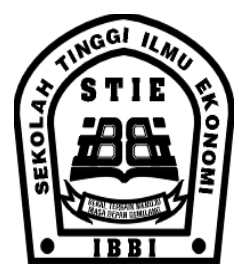

ISSN 1858-3199

JURNAL

MANAJEMEN BISNIS

STIE IBBI

Tabel 4

Hasil Uji Simultan (Uji F) ANOVA ${ }^{b}$

\begin{tabular}{|l|r|r|r|r|r|}
\hline Model & $\begin{array}{r}\text { Sum of } \\
\text { Squares }\end{array}$ & df & $\begin{array}{r}\text { Mean } \\
\text { Square }\end{array}$ & F & Sig. \\
\hline Regression & 880.957 & 3 & 293.652 & 48.517 & $.000^{\mathrm{a}}$ \\
Residual & 581.043 & 96 & 6.053 & & \\
Total & 1462.000 & 99 & & & \\
\hline
\end{tabular}

a. Predictors: (Constant), Lokasi, Kualitas_Produk, Kualitas_Pelayanan

b. Dependent Variable: Kepuasan_Konsumen

Sumber: Data primer yang diolah, 2014

Dari hasil uji ANOVA atau uji $\mathrm{F}$ pada Tabel 4 didapatkan $\mathrm{F}_{\text {hitung }}$ sebesar 48,517 dengan tingkat signifikansi sebesar 0,000. Karena 48,517 $>2,70$ dan $0,000<0,05$ maka model regresi dapat digunakan untuk memprediksi kepuasan konsumen $(\mathrm{Y})$ atau dikatakan bahwa variabel $\mathrm{X}_{1}, \mathrm{X}_{2}$, dan $\mathrm{X}_{3}$ secara bersama-sama berpengaruh secara nyata terhadap variabel Y.

\section{Uji Parsial (Uji t)}

Uji t dimaksudkan untuk mengetahui seberapa jauh pengaruh satu variable independen (lokasi, kualitas produk, dan kualitas pelayanan) secara individual dalam menerangkan variabel dependen (kepuasan konsumen). Kriteria pengujian dengan tingkat signifikansi $(\alpha)=0,05$ ditentukan sebagai berikut :

1. $\mathrm{t}_{\text {hitung }}<\mathrm{t}_{\text {tabel }}$, maka $\mathrm{H}_{0}$ diterima

2. $t_{\text {hitung }}>\mathrm{t}_{\text {tabel }}$, maka $\mathrm{H}_{0}$ ditolak

Hasil analisis uji t adalah sebagai berikut:

1.Nilai $t_{\text {hitung }}$ pada variabel Lokasi $\left(\mathrm{X}_{1}\right)$ adalah sebesar 2,751 dengan tingkat signifikansi 0,007 . Karena 2,751 $>1,9840$ dan $0,000<0,05$ maka $\mathrm{H}_{0}$ ditolak dan $\mathrm{H}_{1}$ diterima.

Kesimpulan : Variabel lokasi berpengaruh positif dan signifikan terhadap kepuasan konsumen .

2. Nilai $t_{\text {hitung }}$ pada variabel Kualitas Produk $\left(\mathrm{X}_{2}\right)$ adalah sebesar 3,068 dengan tingkat signifikansi 0,003. Karena 3,068 > 1,9840 dan 0,003 <0,05 maka $\mathrm{H}_{0}$ ditolak dan $\mathrm{H}_{1}$ diterima.

Kesimpulan: Variabel kualitas produk berpengaruh positif dan signifikan terhadap kepuasan konsumen .

3. Nilai $t_{\text {hitung }}$ pada variabel Kualitas Pelayanan $\left(\mathrm{X}_{3}\right)$ adalah sebesar 2,386 dengan tingkat signifikansi 0,019. Karena $2.386>1,9840$ dan $0,019<0,05$ maka $\mathrm{H}_{0}$ ditolak dan $\mathrm{H}_{1}$ diterima.

Kesimpulan : Variabel kualitas pelayanan berpengaruh positif dan signifikan terhadap kepuasan

konsumen .

Dari hasil pengujian Goodness of Fit, dapat disimpulkan bahwa variabel-variabel independen dalam penelitian ini mampu menerangkan mengenai 59\% variasi kepuasan konsumen. Sedangkan sisanya $41 \%$ dijelaskan oleh variabel lain yang tidak dimasukkan dalam penelitian ini.

\section{PEMBAHASAN}

Dari ketiga variabel independen yang diuji secara individual yang paling dominan dalam mempengaruhi kepuasan konsumen pasar tradisional di kecamatan Medan Johor adalah kualitas produk (dengan koefisien 0,391). Variabel berikutnya yang memiliki peran yang cukup besar dalam mempengaruhi kepuasan konsumen pasar 

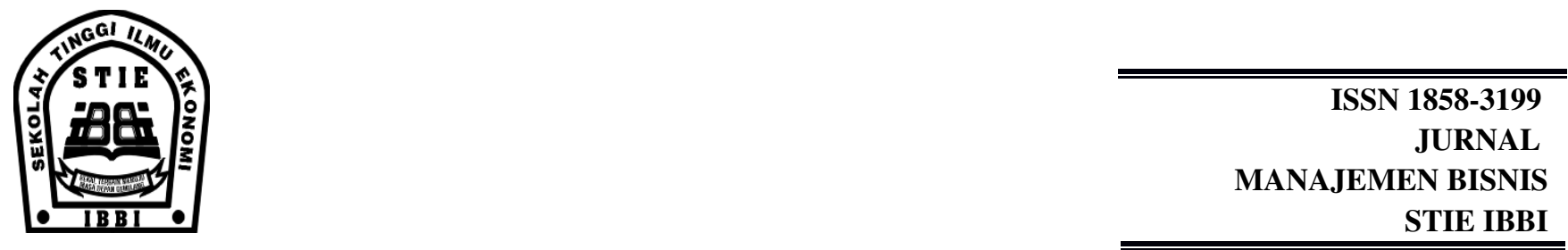

tradisional di kecamatan Medan Johor adalah kualitas pelayanan (dengan koefisien 0,291). Terakhir, variabel yang juga berpengaruh terhadap kepuasan konsumen pasar tradisional di kecamatan Medan Johor adalah variabel lokasi (dengan koefisien 0,204). Semua variabel independen dalam penelitian ini berpengaruh positif terhadap kepuasan konsumen pasar tradisional di kecamatan Medan Johor. Hasil dari uji t menunjukkan bahwa semua variabel independen, yakni lokasi, kualitas produk, dan kualitas pelayanan mempunyai signifikasi kurang dari 0,05. Dari variabel-variabel independen pada penelitian ini, pengaruh yang paling dominan terhadap variabel dependen adalah kualitas produk, berarti variabel ini adalah yang paling penting dalam menentukan kepuasan konsumen pasar tradisional di kecamatan Medan Johor.

Variabel kualitas produk berpengaruh secara signifikan terhadap kepuasan konsumen pasar tradisional di kecamatan Medan Johor dengan nilai $t_{\text {hitung }}$ sebesar 3,068 dan tingkat signifikasi sebesar 0,003. Pasar tradisional di kecamatan Medan Johor yang telah dikenal oleh masyarakat luas dalam memenuhi kebutuhan masyarakat sehari-hari maupun kebutuhan rumah tangga lainnya. Persepsi kualitas yang tinggi akan suatu produk sangat berpengaruh terhadap tingkat kepuasan konsumen. Hal ini berkaitan langsung dengan harapan kepuasan konsumen yang dilakukan di pasar tradisional di kecamatan Medan Johor dalam jangka panjang. Konsumen menilai kualitas dari suatu produk berdasarkan berbagai informasi yang didapatnya baik melalui pengalaman menggunakan produk itu sendiri, maupun dari pertukaran informasi dengan orang lain (word of mouth). Dari penelitian yang dilakukan terhadap persepsi konsumen terhadap kualitas produk, responden mengakui bahwa produk-produk pasar tradisional di kecamatan Medan Johor memiliki variasi produk yang banyak/beragam. Selain itu, produk yang dijual pasar tradisional di kecamatan Medan Johor sudah cukup berkualitas baik sesuai harapan konsumen. Dalam proses penataannya pun menggunakan peralatan-peralatan cukup baik, mesin press, dan lain sebagainya.

Variabel lokasi berpengaruh secara signifikan terhadap kepuasan konsumen pasar tradisional di kecamatan Medan Johor dengan nilai $t_{\text {hitung }}$ sebesar 2,751 dan tingkat signifikasi sebesar 0,007. Persepsi lokasi yang baik akan sangat berpengaruh terhadap kepuasan konsumen. Lokasi merupakan faktor yang sangat berperan sebagai dasar konsumen untuk memilih belanja produk-produk kebutuhan rumah tangga. Lokasi pasar ini mudah dijangkau sarana transportasi umum, dapat dilihat dengan jelas dari jalan raya, nyaman untuk transaksi jual beli, serta peraturan pemerintah dalam mengatur pasar ini agar lebih baik merupakan faktor kunci terhadap kesan yang akan dirasakan konsumen selama berada di pasar tradisional kecamatan Johor Medan.

Variabel kualitas pelayanan berpengaruh secara signifikan terhadap kepuasan pelanggan pasar tradisional di kecamatan Medan Johor dengan nilai $t_{\text {hitung }}$ sebesar 2,386 dan tingkat signifikasi sebesar 0,019. Persepsi kualitas pelayanan yang baik akan sangat berpengaruh terhadap kepuasan konsumen. Pelayanan yang diberikan merupakan faktor yang sangat berperan sebagai dasar pelanggan untuk memilih produk yang ditawarkan. Sarana yang tersedia di pasar ini cukup mendukung kenyamanan konsumen, penjual di pasar ini sudah memberikan pelayanan yang cukup ramahan, serta cepat tanggap dan kesigapan penjual dalam memberikan pelayanan kepada konsumen merupakan faktor kunci terhadap kesan yang akan dirasakan pelanggan selama berada di pasar tradisional di kecamatan Medan Johor.

\section{PENUTUP}

Kesimpulan yang dapat dihasilkan berdasarkan karakteristik responden dari total responden adalah perempuan. Hal ini bisa disebabkan karena perempuan dinilai cenderung lebih konsumtif dan perempuan lebih memiliki tugas berbelanja untuk memenuhi kebutuhannya sehari-hari dibandingkan dengan laki-laki. Pendidikan responden didominasi oleh responden yang berpendidikan terakhir tamat SMA. Dari hasil tabulasi lama berlangganan secara keseluruhan sekitar 5-10 tahun. Jumlah konsumen paling banyak di pasar tradisional Kecamatan Medan Johor memiliki pekerjaan sebagai karyawan swasta. Berdasarkan pengujian pada uji validitas dan raliabilitas, diketahui bahwa seluruh indikator dalam penelitian ini adalah valid dan reliabel. 

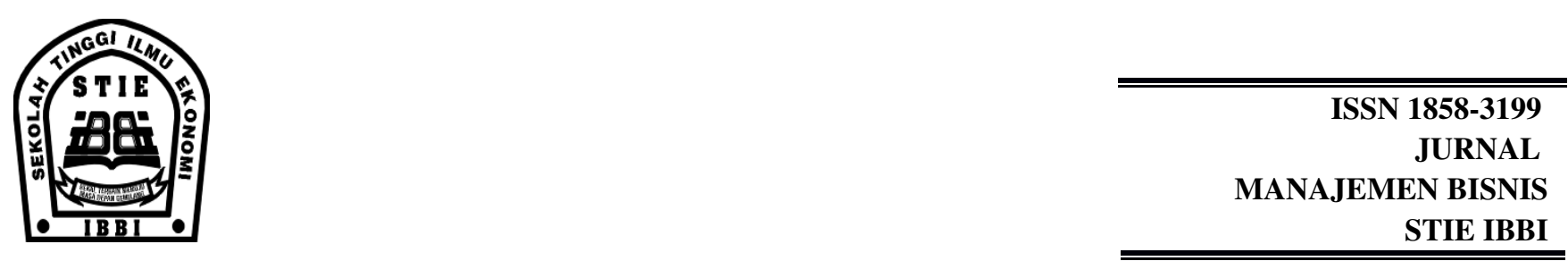

Dari hasil pengujian Goodness of Fit, dapat disimpulkan variabel-variabel independen dalam penelitian ini mampu menerangkan variasi kepuasan konsumen. Kemudian dari hasil uji $\mathrm{F}$ memperlihatkan bahwa variabel independen yang digunakan dalam penelitian ini, yakni lokasi, kualitas produk, dan kualitas pelayanan layak untuk menguji variabel dependen, yakni kepuasan konsumen.

Adapun implikasi penelitian ini adalah dalam menata pasar tradisional agar memiliki daya saing yang unggul terhadap pasar modern yang semakin berkembang dewasa ini. Pemerintah Kota Medan menciptakan model supaya para pedagang dapat meningkatkan kualitas pelayanannya dalam memberikan pelayanan terhadap pelanggan. Berdasarkan item tersebut di atas barang dagangan dengan cara menjaga mutu barang dagangan, menambah keragaman barang dagangan yang sesuai dengan karakteristik konsumen yang berbelanja dan segera mengganti barang daganga yang mungkin sudah rusak. Perusahaan Daerah Pasar menjaga kebersihan baik didalam maupun diluar pasar, memperhatikan penataan dan pengelompokan barang dagangan dan menjaga kenyaman pembeli dalam berbelanja, meletakkan pasar tradisional berada dilokasi yang sangat strategis sehingga mudah dijangkau, selanjutnya produk yang dijual dipasar tradisional sesuai dengan kebutuhan di kecamatan Medan Johor, dan meletakkan papan informasi sehingga pelanggan dapat dengan mudah mengetahui letak dan informasi produk yang dijual.

Keterbatasan yang dialami adalah pada saat input data dikarenakan calon responden enggan diwawancarai dan menjawab kuesioner yang diberikan dengan berbagai alasan, mulai dari keengganan menerima dan mengisi angket kuesioner sampai dengan keterbatasan waktu berada di pasar tersebut untuk berbelanja. Hal ini dimungkinkan karena mobilitas pada masyarakat yang berburu waktu dengan kegiatan lainnya, sehingga waktu berada di pasar tersebut terbatas.

Diharapkan pemerhati peneliti berikutnya agar melakukan penelitian serupa pada pasar tradisional di Kecamatan Medan Johor setelah penelitian ini dilaksanakan sehingga dapat diketahui perubahaan tingkat kepuasan

\section{DAFTAR PUSTAKA}

Arinanda, Hendrikus. 2009. Analisis Variabel Pembentuk Kepuasan Konsumen Pada Ritel Minimarket Alfamart dan Indomaret Di Wilayah Pesanggrahan Jakarta Selatan,Jakarta: Universitas Gunadarma.

Djarwanto, 2008. Statistik Sosial Ekonomi, Yogyakarta : Penerbit BPFE. Ghanimata, Fifyanita dan Kamal, Mustafa.2012, Analisis Pengaruh Harga,Kualitas Produk, Dan Lokasi Terhadap Keputusan Pembelian, ( Studi pada Pembeli Produk Bandeng Juwana Elrina Semarang ), Semarang : jurnal Volume 1 No 1. Universitas Diponegoro.

Ghozali, Imam, 2005, Aplikasi Analisis Multivariate Dengan Program SPSS, Semarang : Penerbit Universitas Dipenegoro.

Kotler, 2004, Manajemen Pemasaran, Jakarta : Salemba Empat, Prince hall. Kotler.P, dan Keller. Kelvin, 2008, Manajemen Pemasaran, Jakarta : PT. Indeks. Kotler, Philips. 2004. Manajemen Pemasaran Jilid 2. Terjemahan Drs. BenyaminMolan.Jakarta : PT Indeks Kelompok Gramedia.

Kotler, P. dan Amstrong, Group. 2008. Dasar-Dasar Pemasaran, Edisi Kesembilan Jilid 1. Jakarta : Penerbit PT. Indeks Gramedia

Lupiyoadi, Rambat, 2013, Manajemen Pemasaran Jasa : Berbasis Kompetensi, Jakarta : Penerbit Salemba Empat. Mowen,C, John. 2002. Perilaku Konsumen. Jakarta : Penerbit Erlangga.

Marno, Nugroho dan Ratih, Paramita. 2009. Analisis Pengaruh Lokasi, Keanekaragaman terhadap Keputusan Berbelanja dan Loyalitas Konsumen di Carefour Semarang, jurnal Ekobis vol 10, no 1 Januari 2009.

Putri, S. Rahayu. 2013. Analisis Pengaruh Harga dan Lokasi Terhadap Kepuasan Konsumen Dalam Berbelanja 

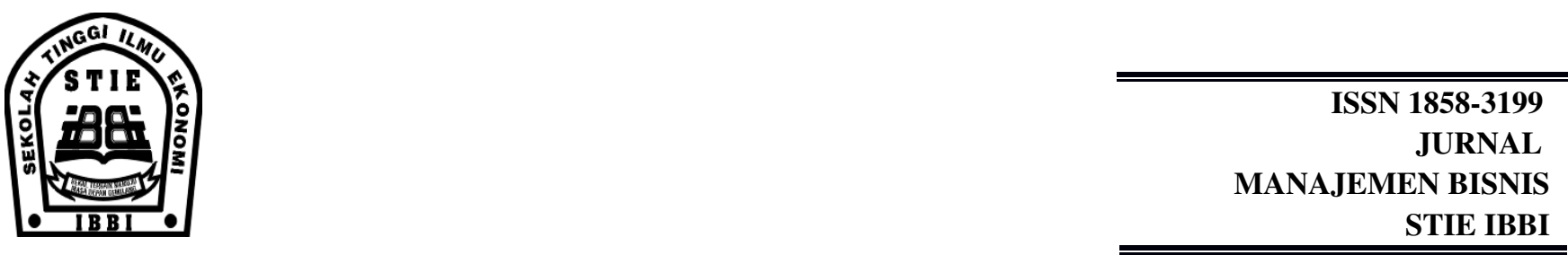

(Studi Kasus pada Pelanggan Gelael Supermarket Ciputra Semarang). Semarang : UNDIP.

Raharjani, Jeni. 2005. Analisis Faktor yang Mempengaruhi Keputusan Pemilihan Pasar Swalayan Sebagai Tempat Berbelanja. Jurnal Studi Manajemen dan Organisasi, Vol. 2, No. 1

Rahma, Talitha L. Halim,Verina S . V. Hariyato Heru. 2012. Hubungan Antara Kualitas layanan Dan Harga Dengan Kepuasan Konsumen Online Shopping Pada Mahasiswi Unversitas Surabaya Universitas SurabayaCalyptra. Surabaya : Jurnal Ilmiah Mahasiswa Universitas Surabaya Vol.1 No.1 (2012)

Sugiono. 2008. Statistika Untuk Penelitian. Bandung : Penerbit PT Alfabeta. Swastha, Basu. 2010. Manajemen Penjualan. Edisi 3, Yogyakarta : BPFE

Tjiptono, Fandy. 2005. Prinsip- Prinsip Total Quality Service. Yogyakarta : Andi. Tjiptono, F dan Chandra, G. 2005. Service Quality and Satisfaction. Yogyakarta : Andi Tjiptono, Fandy dan Chandra, Gregorius.2013. Pemasaran Strategi, Yogyakarta : Penerbit Andi.

Wulandari, Nur. 2013. Analisis Pengaruh Kualitas Prduk, Kualitas Pelayanan dan Lokasi Terhadap Kepuasan Konsumen (Studi Kasus Konsumen Kopikita Semarang). Semarang : UNDIP 